\title{
REPRESENTASI (EKSTERNAL-INTERNAL) PADA PENYELESAIAN MASALAH MATEMATIKA
}

\author{
Achmad Faruq ${ }^{1}$; Ipung Yuwono²; Tjang Daniel Chandra ${ }^{3}$ \\ ${ }^{1,2,3}$ Jurusan Pendidikan Matematika, Universitas Negeri Malang
}

\begin{abstract}
This study aimed to describe the pictorial and schematic representations of student understanding. The subjects were 31 students of grade VIII. The results of this study is two pictorial representations (right and wrong) and two schematic representation (right and wrong). Representation understanding of student described as follows: translational stage, students read the word problem to identify relational statements and quantity, then he transforms the mathematical idea into another form that is more easily understood. Integration stage, students identifying relational relationships between mathematical ideas to be organized into a scheme or image. Solution stage, students devise a solution based on the scheme or image that was created, and then perform calculations and check the answer.
\end{abstract}

Keywords: Representational; Pictorial; Schematic; Mathematical problems.

\section{PENDAHULUAN}

Pembelajaran matematika bukan hanya sebagai proses penyampaian informasi seperti aturan, definisi, dan prosedur untuk dihafal siswa. Akan tetapi, guru sebagai penyampaian informasi kepada siswa harus melibatkan siswa secara aktif dalam proses pembelajarannya. Keikutsertaan siswa secara aktif akan memberikan stimulus positif terhadap pemahaman konsep-konsep matematika yang dipelajari. Hal ini sesuai dengan prinsip-prinsip konstruktivisme yakni pengetahuan dibangun oleh siswa sendiri, baik secara individual atau secara sosial. Pengetahuan tidak dapat dipindahkan dari guru ke siswa, kecuali melalui keaktifan siswa dalam menalar dan mengaitkan dengan informasi yang dimiliki siswa sebelumnya. Bruner mengatakan bahwa informasi baru merupakan penghalusan dari informasi sebelumnya yang dimiliki seorang siswa. Peran guru membantu menyediakan sarana dan situasi agar proses konstruksi siswa berjalan sesuai dengan yang diharapkan (Bell, 1978).

Setiap siswa mempunyai cara yang berbeda untuk mengonstruksi pengetahuannya (Kusaeri, 2012). Dalam hal ini, sangat dimungkinkan siswa mencoba berbagai macam representasi (eksternal) dalam memahami suatu konsep. Janvier menyatakan konsep representasi merupakan salah satu konsep psikologi yang digunakan dalam pendidikan 
matematika untuk menjelaskan beberapa fenomena penting tentang cara berpikir siswa (Kartini, 2009). Representasi digunakan untuk menjelaskan ide-ide abstrak matematis yang terdapat dalam suatu masalah. Representasi juga merupakan bagian penting dari aktifitas berpikir. Solso (1998) menyatakan bahwa berpikir adalah sebuah proses dimana representasi mental baru dibentuk melalui transformasi informasi dengan interaksi dimana sekumpulan atribut-atribut mental seperti penilaian, abstraksi, logika, imajinasi, dan penyelesaian masalah. Gagatnis \& Shiakalli mengungkapkan bahwa representasi-representasi berbeda yang mengacu pada konsep yang sama akan saling melengkapi dan berkontribusi untuk pemahaman (Kartini, 2009).

Representasi terbagi menjadi dua, yaitu representasi eksternal dan representasi internal (Adu-Gyamfi, 2003). Janvier menjelaskan bahwa representasi eksternal menunjukkan wujud secara fisik dari suatu ide matematis (Kartini, 2009). Representasi eksternal meliputi representasi verbal (tertulis), representasi visual (piktorial dan skematik), dan representasi simbolik (persamaan yang menunjukkan hubungan dua atau lebih kuantitas). Sedangkan representasi internal adalah struktur kognitif "unique" yang memuat konsep matematika dan konsep-konsep lainnya (As'ari, 2001). Hudiono (2005) mengatakan bahwa suatu aktivitas yang menghasilkan bentuk representasi eksternal sebagai suatu bentuk yang dapat diobservasi adalah menggambarkan proses yang terjadi secara internal di dalam pikiran siswa. Melalui interaksi siswa dengan representasi eksternal membentuk skema pengetahuan siswa. Untuk memikirkan dan mengomunikasikan gagasan-gagasan matematika, siswa perlu merepresentasikannya dengan cara-cara tertentu. Dengan demikian, apabila siswa memiliki akses representasirepresentasi dari gagasan-gagasan yang mereka tampilkan, maka mereka memiliki sekumpulan alat yang siap secara signifikan akan memperluas kapasitas mereka dalam berpikir matematis (NCTM, 2000).

Keberhasilam penyelesaian masalah matematis dalam bentuk soal cerita dapat diamati dari aktivitas siswa ketika mengonstruksi representasi dari masalah dan menggunakan representasi dalam bentuk kata-kata, grafik, tabel, dan persamaanpersamaan dan simbol matematika (Neria \& Amit, 2004). Hegarty \& Kohzenikov (1999) menyatakan bahwa terdapat dua tipe representasi yang berkaitan dengan keberhasilan siswa dalam menyelesaikan soal cerita matematika, yaitu (a) representasi piktorial, menampilkan secara visual dari objek yang dijelaskan dalam soal cerita, dan (b) representasi skematik, mendeskripsikan hubungan spasial dalam soal cerita. 
Muttaqien (2016) menjelaskan bahwa representasi piktorial berarti mengodekan deskripsi objek dalam soal cerita, sedangkan representasi skematik mengodekan deskripsi relasi dalam soal cerita

Terdapat tahap-tahap penyelesaian masalah dalam soal cerita untuk mengeksplorasi representasi siswa. Mayer menyatakan bahwa terdapat 3 tahap yang diperlukan, yaitu (a) tahap translasi, (b) tahap integrasi, dan (c) tahap solusi (Krawec, 2010). Pada tahap translasi, siswa membaca soal cerita yang melibatkan transformasi pernyataan dari soal cerita menjadi bentuk lain yang dimengerti. Pada tahap integrasi, siswa memvisualisasi ide dengan membuat gambar atau skema. Tahap solusi, menyajikan deskripsi siswa dalam melakukan komputasi dan memeriksa langkah penyelesaian.

Berdasarkan pemaparan sebelumnya, salah satu hal yang menjadi ketertarikan peneliti adalah ingin melihat proses terbentuknya pemahaman matematis (representasi internal) siswa guna diperolehnya hasil akhir benar dan diperolehnya hasil akhir salah. Penelitian yang berkaitan tentang representasi internal masih belum banyak dilakukan. Hal ini dikarenakan representasi internal tidak dapat diamati secara langsung. Jalan satu-satunya yaitu melalui representasi eksternalnya. Penelitian ini diharapkan dapat mendeskripsikan keterkaitan ketepatan konstruksi representasi internal siswa dengan penyelesaian masalah.

\section{METODE PENELITIAN}

Penelitian ini berjenis deskriptif dengan pendekatan kualitatif. Deskripsi representasi disajikan secara naratif atau melalui uraian kalimat-kalimat. Cresswell (2012) mengungkapkan bahwa penelitian dengan menganalisis data untuk dideskripsikan menggunakan analisis teks dan menafsirkan makna yang lebih luas dari temuan serta mengumpulkan data berupa kata-kata dari sejumlah orang (subjek penelitian) disebut dengan penelitian dengan pendekatan kualitatif. Penelitian dilakukan di SMPN 3 Sidoarjo pada 7 Mei 2016. Subjek penelitian sebanyak 31 siswa kelas 8-G. Subjek dipilih berdasarkan hasil tes penyelesaian masalah dengan melihat lan gkahlangkah penyelesaian masalah dan dilihat dari sudut pandang ada tidaknya representasi yang dilakukan pada saat tes. Adapun instrumen penelitian ini berupa soal cerita tentang menentukan banyak siswa dalam suatu barisan. Instrumen tersebut disajikan pada Gambar 1. 


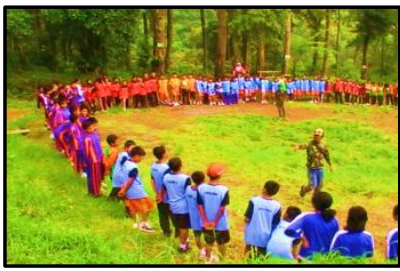

Seorang Guru olah raga menyuruh murid-muridnya untuk berdiri sehingga membentuk lingkaran dengan jarak antar murid sama. Jika setiap murid diberi nomor secara berurutan dan murid nomor 12 berseberangan langsung dengan murid nomor 28, berapa banyak murid dalam lingkaran tersebut?

Gambar 1.

Instrumen Penelitian

Analisis data dalam penelitian ini dimulai dari reduksi data, transkrip dan pengambilan kesimpulan. Skema ideal representasi piktorial maupun skematik dalam menyelesaikan soal cerita pada tahap translasi, tahap integrasi dan tahap solusi disajikan dalam Gambar 2 (Muttaqien, 2006).

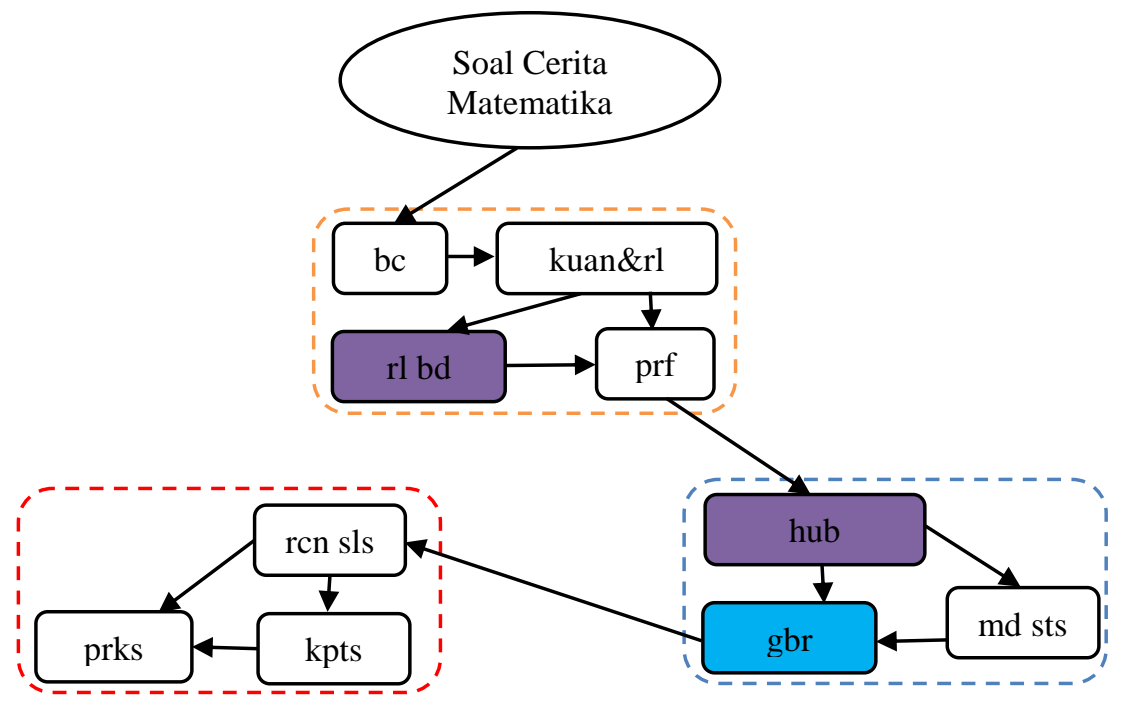

Gambar 2.

Skema Representasi Ide-Ide Matematis dalam Penyelesaian Soal Cerita Matematika

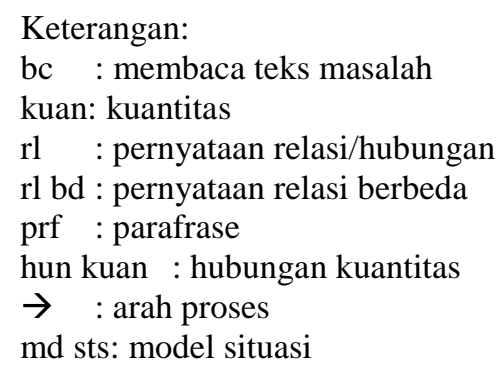

$$
\begin{aligned}
& \text { gbr : gambar } \\
& \text { rcn sls: rencana solusi } \\
& \text { kpts : komputasi } \\
& 0 \text { : ciri piktorial } \\
& 0 \text { : ciri skematik } \\
& \\
& \text { : Fase Translasi } \\
&
\end{aligned}
$$

Representasi piktorial maupun skematik masing-masing memiliki karakteristik. Karakteristik tersebut dapat berkembang bergantung dengan tipe soal cerita yang diselesaikan. Ada soal cerita yang mengandung banyak ide-ide matematis yang perlu 
direpresentasi, ada pula yang lebih sederhana representasinya. Namun, secara umum indikator representasi dalam penyelesaian soal cerita disajikan dalam Tabel 1 berikut.

Tabel 1.

Indikator Representasi dalam Menyelesaikan Masalah

\begin{tabular}{|c|c|}
\hline Deskripsi & Tahap Penyelesaian \\
\hline $\begin{array}{l}\text { Siswa mentransformasi } \\
\text { pernyataan relasional } \\
\text { menjadi kata kunci, } \\
\text { menghubungkan antara } \\
\text { kuantitas, namun tidak } \\
\text { menghubungkan dengan } \\
\text { pernyataan relasional } \\
\text { untuk membuat gambar } \\
\text { lengkap dan melakukan } \\
\text { perhitungan } \\
\text { berdasarkan kata kunci. }\end{array}$ & $\begin{array}{l}\text { 1. Translasi } \\
\text { a. Membaca soal ceritauntuk menemukan kuantitas dan } \\
\text { pernyataan relasional } \\
\text { b. Identifikasi pernyataan relasional yang dianggap sebagai } \\
\text { fakta penting. } \\
\text { c. Transformasi pernyataan relasional menjadi kata kunci. } \\
\text { 2. Integrasi } \\
\text { a. Mengidentifikasi sebagian hubungan. } \\
\text { b. Mengintegrasi sebagian pernyataan dari teks soal cerita. } \\
\text { c. Membuat gambar dari pernyataan dan kuantitas. } \\
\text { 3. Solusi } \\
\text { a. Rencana solusi, membuat dugaan kuantitas. } \\
\text { b. Melakukan serangkaian komputasi. } \\
\text { c. Memeriksa jawaban. }\end{array}$ \\
\hline $\begin{array}{l}\text { Siswa mengidentifikasi } \\
\text { dan mentransformasi } \\
\text { pernyataan relasional } \\
\text { menjadi bentuk lain } \\
\text { yang berbeda, } \\
\text { menghubungkan } \\
\text { kuantitas dan } \\
\text { pernyataan relasional } \\
\text { untuk membuat skema, } \\
\text { dan melakukan } \\
\text { perhitungan } \\
\text { berdasarkan hubungan } \\
\text { tersebut. }\end{array}$ & $\begin{array}{l}\text { 1. Translasi } \\
\text { a. Membaca soal cerita menggunakan pengetahuan linguistik } \\
\text { untuk mengidentifikasi pernyataan relasional dan kuantitas. } \\
\text { b. Transformasi pernyataan relasional menjadi bentuk lain } \\
\text { yang dimengerti. } \\
\text { c. Parafrase, rewording soal cerita dalam bentuk berbeda } \\
\text { tanpa mengubah makna substansial. } \\
\text { 2. Integrasi } \\
\text { a. Identifikasi hubungan-hubungan antar kuantitas dan } \\
\text { pernyataan relasional untuk diorganisasi ke dalam skema- } \\
\text { skema mental. } \\
\text { b. Transformasi dari situasi ke model. } \\
\text { c. Membuat diagram dari model situasi yang diciptakan. } \\
\text { 3. Solusi } \\
\text { a. Rencana solusi, merencanakan solusi berdasarkan skema } \\
\text { mental dan diagram ke model situasi } \\
\text { b. Komputasi, melakukan serangkaian komputasi berdasarkan } \\
\text { skema dan gambar. } \\
\text { c. Memeriksa jawaban. }\end{array}$ \\
\hline
\end{tabular}

(Sumber: adaptasi dari Muttaqien, 2016)

\section{HASIL DAN PEMBAHASAN}

Berdasarkan hasil penelitian ini diperoleh 18 siswa yang menyelesaikan soal cerita menggunakan skematik dan 12 siswa menggunakan representasi piktorial serta 1 siswa menyelesaikan tanpa representasi. Pada representasi piktorial diperoleh 8 siswa 
menjawab benar dan 4 siswa menjawab salah. Sedangkan pada representasi skematik diperoleh 13 siswa menjawab dengan benar dan 5 siswa menjawab salah.

Representasi piktorial dengan hasil akhir benar salah satunya dilakukan oleh subjek SR. Sedangkan representasi piktorial dengan solusi yang salah dilakukan oleh subjek DA. Hasil kerja tertulis SR dan DA disajikan berturut-turut dalam Gambar 3 dan Gambar 5.

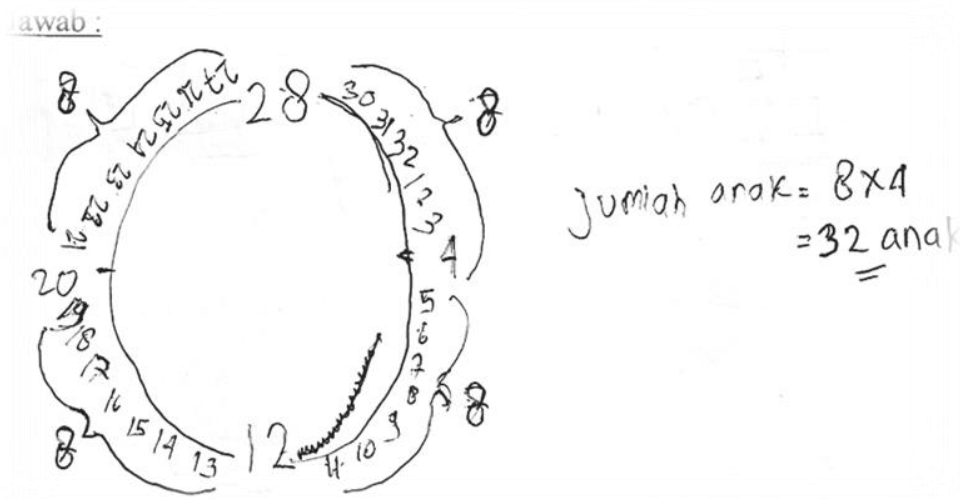

\section{Gambar 3.}

Representasi Piktorial dengan Hasil Akhir Benar oleh SR

Pada tahap translasi, SR mengidentifikasi adanya kuantitas yaitu anak nomor 12 dan anak nomor 28. SR juga menyebutkan pernyataan relasional yaitu anak nomor 12 dan anak nomor 28 berhadapan langsung. SR menyatakan bahwa jarak antara anak nomor 28 ke anak nomor 12 adalah 16 orang. Kemudian ia mengatakan bahwa setengah lingkaran tersebut berisi 16 anak. Demikian juga dengan setengah lingkaran yang lain juga harus berisi 16 anak. Pada tahap integrasi, SR membuat gambar susunan objek lengkap yang membentuk lingkaran. Pada tahap solusi, SR melakukan rencana solusi dengan membuat gambar ilustrasi dari situasi dalam soal. Setelah membuat gambar ilustrasi, SR melakukan komputasi sederhana dengan menjumlahkan kuantitas yang telah diketahui yaitu $8+8+8+8=32$. Hasil akhir yang ditunjukkan SR adalah 32 anak dalam lingkaran. Skema representasi piktorial yang dilakukan oleh SR baik melalui jawaban tertulis dan wawancara disajikan dalam Gambar 4 berikut. 


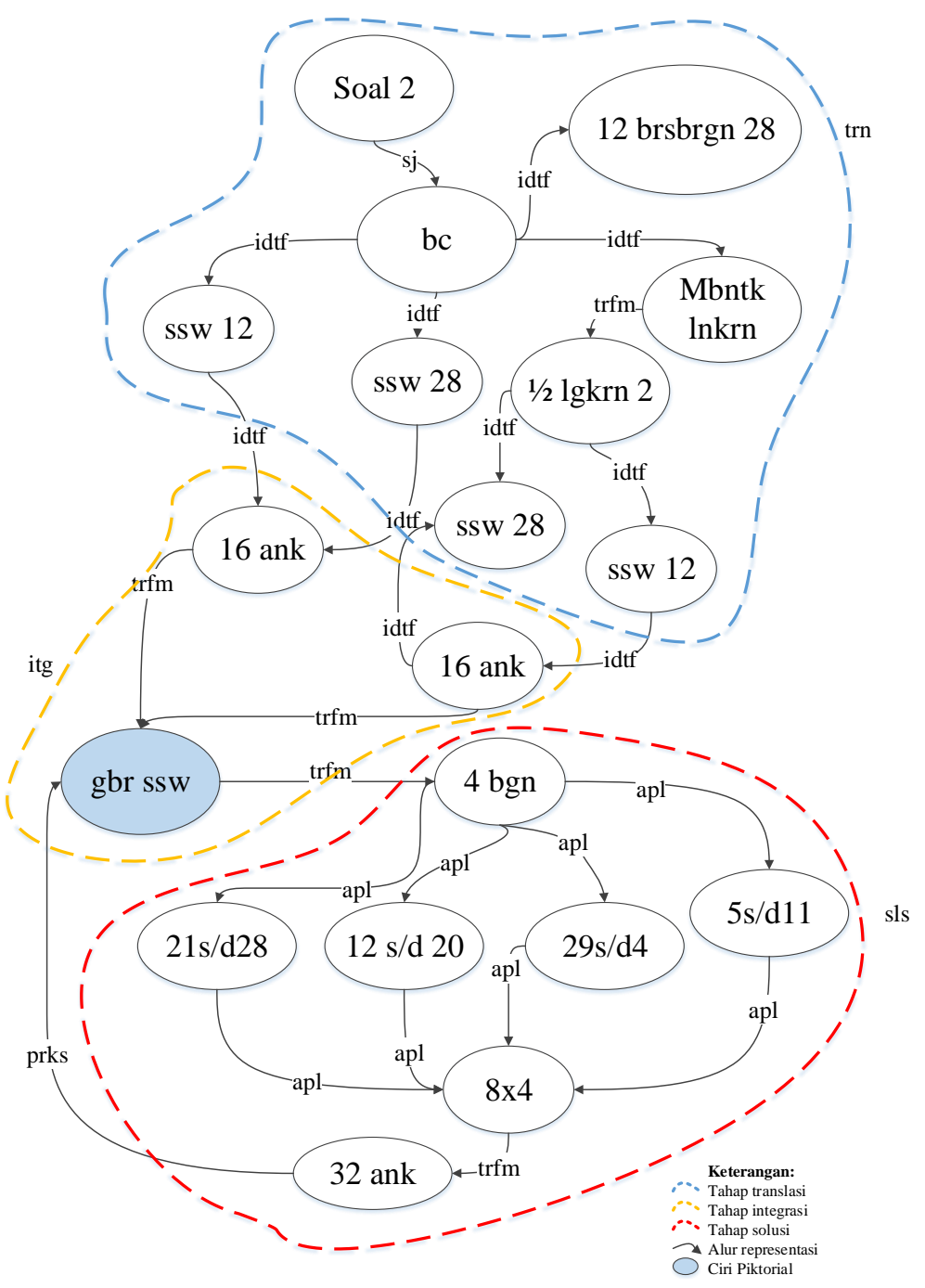

Gambar 4.

Skema Representasi Piktorial oleh SR

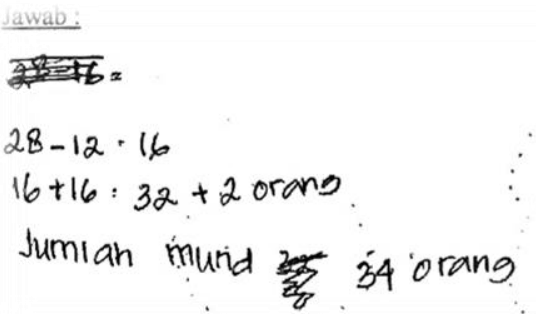

Gambar 5.

Representasi Piktorial dengan Hasil Akhir Salah oleh DA

Pada tahap translasi, DA mengidentifikasi adanya kuantitas yaitu anak nomor 12 dan anak nomor 28. DA juga menyebutkan pernyataan relasional yaitu anak nomor 12 
dan anak nomor 28 berhadapan langsung. DA menyatakan bahwa jarak antara anak nomor 28 ke anak nomor 12 adalah 16 orang. Kemudian ia mengatakan bahwa setengah lingkaran tersebut berisi 16 anak. Dalam tahap ini, DA membuat gambar yang mewakili posisi anak dalam lingkaran. Gambar yang dibuat oleh DA berupa susunan titik-titik yang membentuk lingkaran. Gambar tersebut memuat dugaan keseluruhan anak yang membentuk lingkaran. DA menyatakan bahwa diantara anak nomor 12 sampai anak nomor 28 terdapat 16 anak. Dia menghitung mulai dari anak nomor 12 hingga anak nomor 27. Kemudian DA menghitung lagi mulai dari anak nomor 28 sebanyak 16 urutan. Pada tahap solusi, DA melakukan rencana solusi dengan membuat gambar ilustrasi dari situasi dalam soal. Setelah membuat gambar ilustrasi, DA melakukan komputasi sederhana dengan menjumlahkan kuantitas yang telah diketahui $16+16+2=$ 34. angka 2 merupakan perwakilan dari anak nomor 12 dan anak nomor 28. Hasil akhir yang ditunjukkan DA adalah 34 anak dalam lingkaran. Kemudian DA melakukan refleksi terhadap jawaban yang telah ditulis.

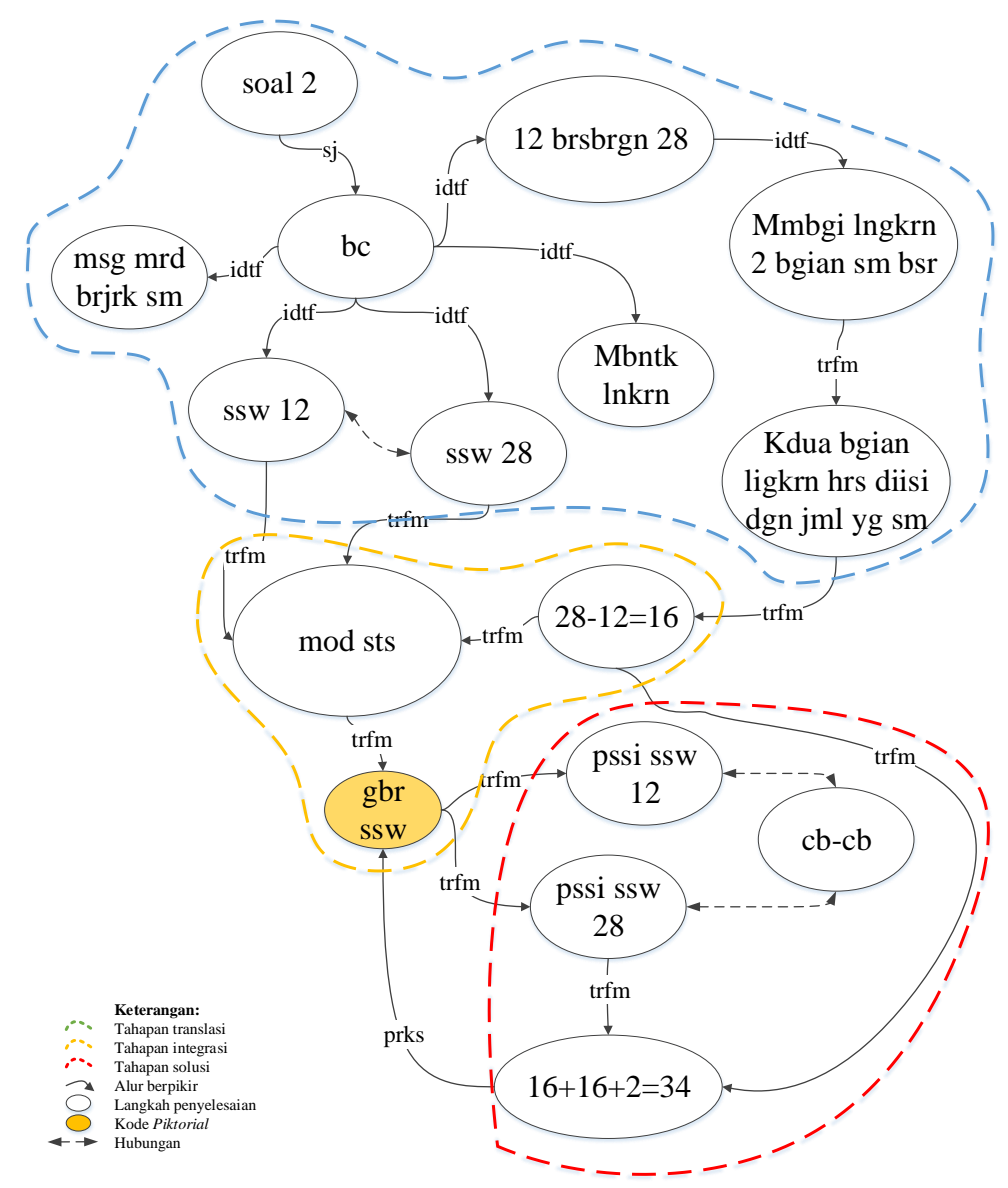

Gambar 6.

Skema Representasi Piktorial Subjek DA 
Representasi skematik dengan hasil akhir benar salah satunya dilakukan oleh subjek RP. Hasil kerja tertulis RP disajikan berturut-turut dalam Gambar 7.

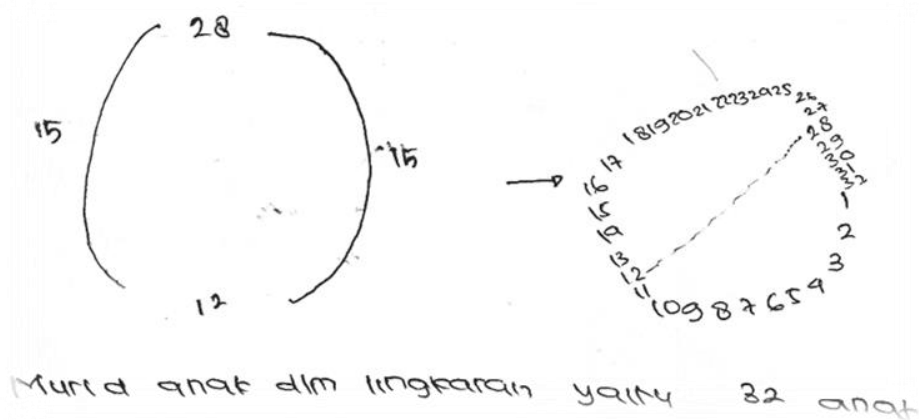

Gambar 7.

Representasi Skematik dengan Hasil Akhir Benar oleh RP

Berdasarkan hasil kerjanya, RP membuat skema yang mengilustrasikan situasi dalam soal cerita tentang banyak siswa dalam barisan melingkar. Menurutnya, dari informasi soal bahwa anak bernomor 12 berhadapan langsung dengan anak nomor 28, kemudian ia membuat skema dimana jika anak nomor 12 dan anak nomor 28 dihubungkan maka akan membagi barisan lingkaran menjadi dua bagian sama besar. Berikut petikan wawancara dengan RP "Ini kan nomor 12 dan 28 berhadapan. Trus jadi kalau dari sini (anak nomor 12) ke sini (anak nomor 28) ada 15 nomer. Jadi sisi satunya (28 hingga 12) juga ada 15 nomer juga....”. Melalui respon RP ini, dia mengeksplorasi informasi yang terdapat dalam soal dan kemudian menghubungkannya secara logis untuk menemukan banyak siswa yang berada di antara anak nomor 12 dan anak nomor 28, yaitu sebanyak 15 anak. Dengan demikian, pada tahap translasi RP melakukan membaca soal sekaligus mengidentifikasi pernyataan relasional "berhadapan" dan kuantitas, mentransformasi penyataan relasional menjadi skema dimana posisi anak nomor 12 dan anak nomor 28 jika dihubungkan akan membagi lingkaran menjadi dua bagian yang sama besar.

Pada tahap integrasi, RP mengidentifikasi hubungan pernyataan relasional dan kuantitas yang ada dalam soal. Ia menyatakan bahwa ada 15 anak yang dapat menempati angka 13 hingga 27. Kemudian RP membuat gambar skema. Pada tahap solusi, RP menghitung bahwa banyak anak dari nomor 28 hingga nomor 12 adalah 15 anak. Sedangkan, dari nomor 1 hingga nomor 12 hanya ada 12 anak. Dari skema yang dibuatnya, Ia menyatakan bahwa sebelum anak nomor 1, ada 4 anak yang berada setelah 
anak nomor 28. Perhitungannya adalah $28+4=32$. Dengan demikian RP menyimpulkan bahwa jumlah anak dalam lingkaran tersebut adalah 32 anak. Skema representasi subjek RP disajikan dalam Gambar 8 di bawah ini.

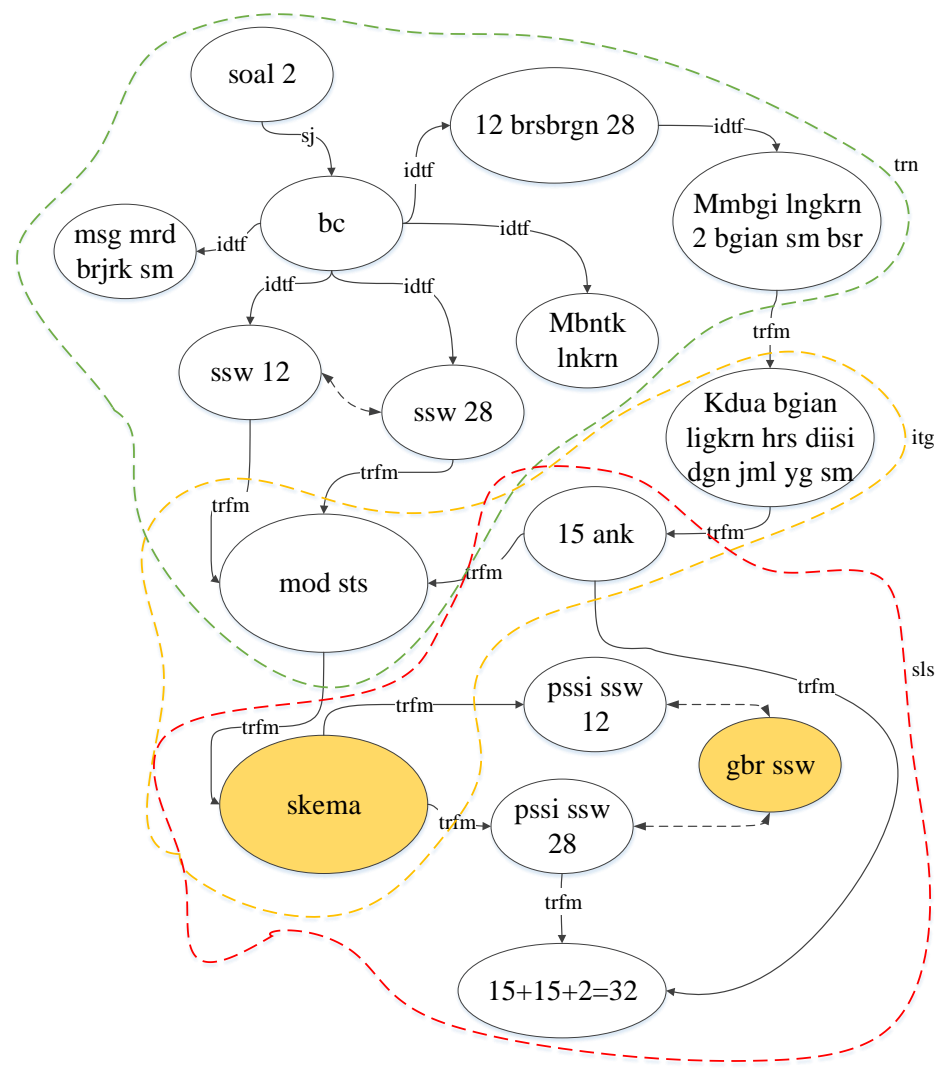

Gambar 8.

Skema Representasi Skematik dengan Hasil Akhir Benar oleh RP

Pada hasil kerja siswa AP ditunjukkan representasi skematik dengan hasil akhir salah. Terdapat kesalahan dalam membuat gambar skema yang ia buat. Akibatnya, proses penyelesaian selanjutnya juga salah dan menghasilkan jawaban yang salah. Hasil kerja siswa AP disajikan dalam Gambar 9 berikut.

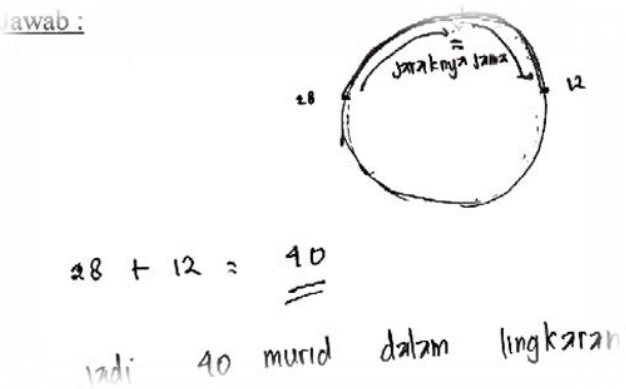

Gambar 9.

Representasi Skematik oleh AP 
Pada tahap translasi, siswa AP menggunakan representasi skematik dalam menyelesaikan soal cerita tentang banyak siswa dalam barisan melingkar. Pada saat translasi, ia mengidentifikasi bahwa anak nomor 12 berhadapan dengan anak nomor 28 . Hal ini berarti barisan lingkaran tersebut terbagi menjadi 2 bagian yang sama besar. Dalam petikan wawancara siswa AP menyebutkan bahwa “... Ini kan 1 dengan 12 sama jaraknya (sambil menunjuk ke skema)..... sedangkan 12 ini berseberangan sama 28 tersebut. Jadi, 1 sama 12 itu jaraknya sama dengan 1 sama 28. jadi 28 harus ditambahkan 12 biar sama". Dalam petikan wawancara tersebut, ia menggunakan acuan anak nomor 1 . Ia berasumsi bahwa anak nomor 1 terletak benar diantara anak nomor 12 dan anak nomor 28 .

Pada tahap integrasi, AP mentransformasi hubungan relasional "berhadapan" dengan operasi penjumlahan. Kemudian berdasarkan transformasi tersebut Ia menentukan banyak siswa dalam lingkaran tersebut adalah 40 siswa. Langkah kerja siswa AP dalam membuat acuan anak nomor 1 sebagai titik tengah antara anak nomor 28 dan anak nomor 12. Hal ini dikarenakan tidak ada yang menjamin dengan pasti bahwa anak nomor 1 berada benar di tengah anak nomor 28 dan anak nomor 12 . Kemudian, hal yang salah lain ditunjukkan oleh siswa AP yaitu dalam mentransfomasi pernyataan relasional "berhadapan" dengan operasi jumlah. Hal ini tidak ada landasan logis yang dapat membenarkan transformasi yang dilakukan siswa AP. Dengan demikian, dalam menyelesaikan soal cerita tentang banyak siswa dalam lingkaran, siswa AP membuat representasi dengan hasil akhir salah. Skema representasi subjek AP digambarkan dalam Gambar 10 sebagai berikut. 


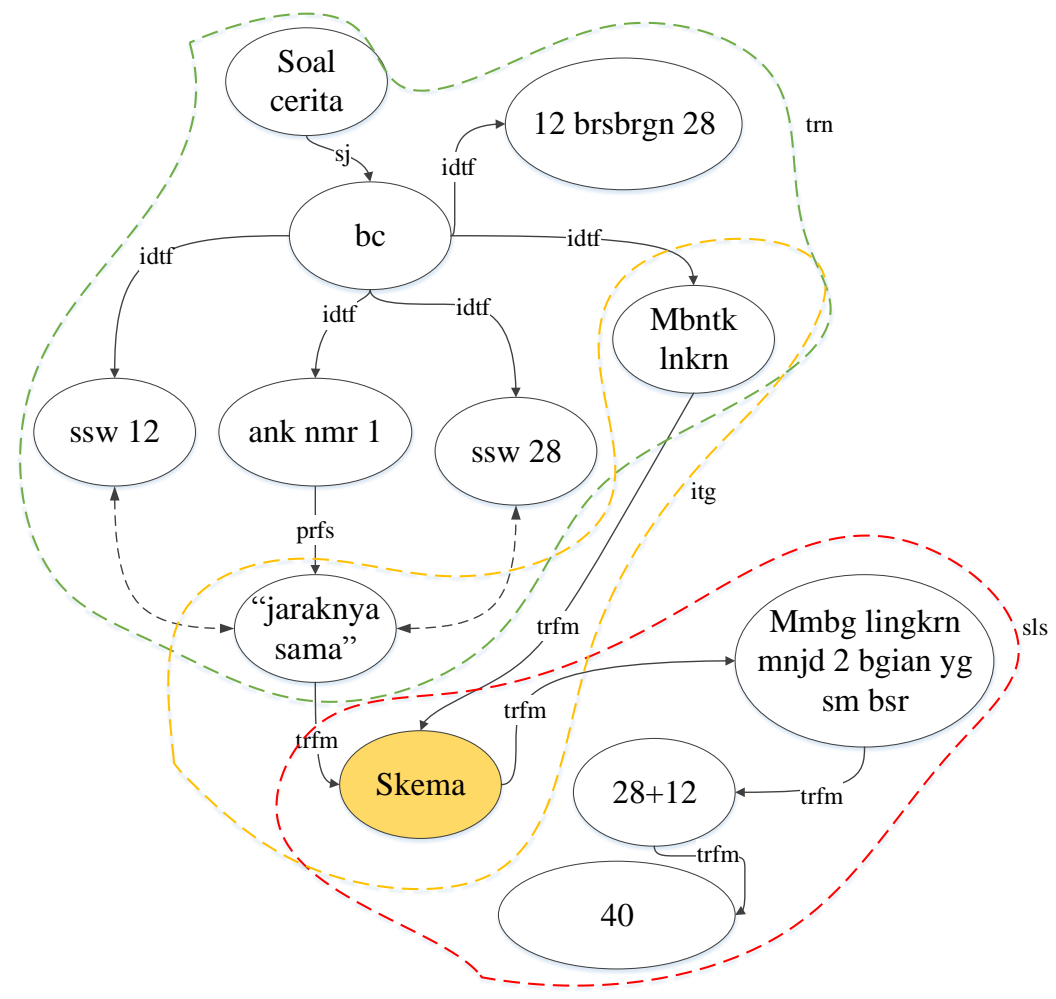

Gambar 10.

Skema Representasi Skematik dengan Hasil Akhir Salah oleh AP

\section{SIMPULAN DAN SARAN}

Penyelesaian soal cerita matematika bergantung dengan representasi, secara khusus pada representasi di tahap translasi dan integrasi. Pada kedua tahap tersebut terjadi aktivitas krusial dimana siswa dapat secara tepat atau tidak tepat dalam merepresentasikan situasi yang terdapat dalam soal cerita. Siswa yang membuat representasi eksternal dengan tepat akan menghasilkan skema pemahaman yang runtut. Sebaliknya, siswa yang tidak tepat dalam mengonstruksi representasi eksternal dari masalah matematis, skema yang dihasilkan tidak beraturan atau ada beberapa unsur yang tidak muncul dalam skema.

Selanjutnya, representasi piktorial terbagi menjadi dua, yaitu representasi piktorial benar dan representasi piktorial salah. Representasi piktorial benar yaitu siswa membuat gambar situasi dari soal cerita kemudian membuat kata kunci dan melakukan komputasi dengan menghasilkan hasil akhir yang benar. Representasi piktorial salah membuat gambar situasi dari soal cerita kemudian membuat kata kunci dan melakukan komputasi dengan menghasilkan hasil akhir yang salah. Representasi skematik dalam penyelesaian soal cerita terdiri dari dua macam, yaitu representasi skematik benar dan representasi 
skematik salah. Representasi skematik benar yaitu siswa membuat skema atau mengungkapkan gambaran mental, dan menentukan relasi yang benar antar pernyataan dalam soal cerita. Sedangkan, representasi skematik salahyaitu siswa membuat skema namun salah dalam menggambar atau sebagian relasi hilang sehingga mengakibatkan jawaban akhir yang salah.

Deskripsi penyelesaian soal cerita untuk menentukan banyak siswa dalam suatu barisan, representasi matematis dijabarkan sebagai berikut. Tahap translasi, siswa membaca soal cerita untuk mengidentifikasi pernyataan relasional dan kuantitas, kemudian ia mentransformasi ide matematis menjadi bentuk lain yang lebih mudah dimengerti. Pada tahap integrasi, mengidentifikasi hubungan relasional antar ide matematis untuk diorganisasi ke dalam skema atau gambar. Pada tahap solusi, siswa merencanakan solusi berdasarkan skema atau gambar yang telah dibuat, kemudian melakukan penghitungan dan memeriksa jawaban.

\section{DAFTAR RUJUKAN}

Adu-Gyamfi, K. (2003). External multiple representations in mathematics teaching. North Carolina State University.

As'ari, A. R. (2009). Representasi: Pentingnya dalam Pembelajaran Matematika. Jurnal Matematika, 7(2), 81-91.

Bell, F. H. (1978). Teaching and learning mathematics (In secondary school). New York: Brown Company Publisher.

Cresswell, J. W. (2012). Educational research. Boston : Pearson.

Hegarty, M., \& Kozhevnikov, M. (1999). Types of visual-spatial representations and mathematical problem solving. Journal of Educational Psychology, 91(4), 684689.

Hudiono, B. (2005). Peran pembelajaran diskursus multi representasi terhadap pengembangan kemampuan matematik dan daya representasi pada siswa SLTP. Diakses pada 2 Nopember 2015, dari http://digilib.upi.edu/digitalview.hp?digital_id=1110.

Kartini. (2009). Peranan representasi dalam pembelajaran matematika. Prosiding Seminar Nasional Matematika dan Pendidikan Matematika, 5 Desember 2009, ISBN 978-979-16353-3-2. Yogyakarta: Jurusan Pendidikan Matematika FMIPA Universitas Negeri Yogyakarta. 
Krawec, J. L. (2010). Problem representation and mathematical problem solving of students of varying math ability. Open Access Dissertations. Paper 455. Miami: University of Miami.

Kusaeri, K. (2012). Pengembangan tes diagnostik dengan menggunakan model DINA, untuk mendapatkan informasi salah konsepsi dalam aljabar. (Doctoral dissertation, UNY).

Muttaqien, A. (2016). Proses representasi pada pemecahan word problem. DISERTASI dan TESIS Program Pascasarjana UM.

National Council of Teachers of Mathematics (NCTM). (2000). Principles and standards for school mathematics. Reston, VA: NCTM Publications.

Neria, D., \& Amit, M. (2004). Students preference of non-algebraic representations in mathematical communication'. In Proceedings of the $28^{\text {th }}$ Conference of the International Group for the Psychology of Mathematics Education (Vol. 3, pp. 409-416).

Solso, R. L. (1998). Cognitive Psychology (5 $5^{\text {th }}$ ed.). Boston: Allyn \& Bacon. 